\title{
NORTHIENAMYCIN AND 8-EPI-THIENAMYCIN, NEW CARBAPENEMS FROM STREPTOMYCES CATTLEYA
}

\author{
Kenneth E. Wilson, August J. Kempf, Jerrold M. Liesch \\ and Byron H. Arison \\ Merck Sharp \& Dohme Research Laboratories, P.O. Box 2000, \\ Rahway, New Jersey 07065, U.S.A.
}

(Received for publication May 27, 1983)

\begin{abstract}
Two new carbapenem antibiotics, northienamycin and 8-epi-thienamycin have been isolated from culture broth of Streptomyces cattleya grown under conditions for thienamycin production. The isolation, structure elucidation and in vitro antibacterial spectra of the new carbapenems are reported. In addition, comparison of the in vitro potency of the corresponding formamidine derivatives to that of MK787 is presented.
\end{abstract}

The discovery of thienamycin (1) in fermentation broth of Streptomyces cattleya in 1976 introduced a new class of naturally occurring $\beta$-lactam antibiotics, the carbapenems. ${ }^{1)}$ Co-produced with thienamycin are $N$-acetylthienamycin ${ }^{2}$ and $N$-acetyldehydrothienamycin. ${ }^{3)}$ Since 1976 , the carbapenem family has grown to include approximately 34 structurally defined members. ${ }^{4 \sim 21}$ )

During subsequent development work on the isolation of thienamycin, two new carbapenems, 9northienamycin (2, northienamycin) and 8-epi-thienamycin (3) were detected. This paper describes the isolation, structural elucidation, and antibacterial spectra of these two compounds. In addition, a comparison of the antibacterial potency of the formamidine derivatives of $\mathbf{2}$ and $\mathbf{3}$ relative to that of $\mathrm{N}$-formimidoylthienamycin (MK787) is presented.

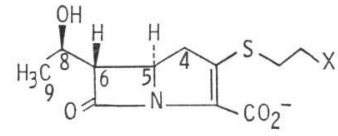

1 (Thienamycin) $\mathrm{X}: \mathrm{NH}_{3}{ }^{+}(5 R, 6 S, 8 R)$

4 (MK-787) X: NH-CH $=\mathrm{NH}_{2}{ }^{+}$

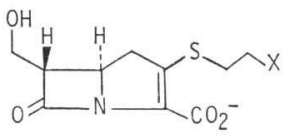

2 (Northienamycin) $\mathrm{X}: \mathrm{NH}_{3}{ }^{+}$ $5 \mathrm{X}: \mathrm{NH}-\mathrm{CH}=\mathrm{NH}_{2}{ }^{+}$

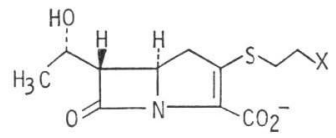

3 (8-epi-Thienamycin) $\mathrm{X}: \mathrm{NH}_{3}{ }^{+}$

$6 \mathrm{X}: \mathrm{NH}-\mathrm{CH}=\mathrm{NH}_{2}{ }^{+}$

\section{Materials and Methods}

\section{Chemicals}

Thienamycin and $N$-formimidoylthienamycin (MK787) are products of Merck Sharp \& Dohme Research Laboratories ${ }^{22,23)}$. The latter was prepared from thienamycin by the reported procedure ${ }^{23}$. Chromatographic media were obtained from the following sources: Dowex AG 1X2, Dowex 50WX2 and Aminex A-5 from Bio-Rad Laboratories, Richmond, CA; Amberlite XAD-2 from Rohm and Haas Co., Philadelphia, and Sephadex G-75 from Pharmacia Fine Chemicals, Piscataway, NJ; Amberlite XAD-2, -400 mesh was prepared by milling commercial resin and sieving. Reference antibiotics were cephalothin (Keflin; Eli Lilly \& Co.) and carbenicillin disodium (Pyopen, Beecham-Massengill). All other chemicals were of reagent grade.

Fermentation

Production of thienamycin by fermentation of $S$. cattleya was by reported procedures. ${ }^{22)}$ 
Antibacterial Assays

Antibacterial activity of partially purified samples was determined by agar disc diffusion assay against Staphylococcus aureus ATCC 6538P using thienamycin or MK787 as standard. Disc diffusion assay results reported in Table 3 employed the KIRBY-BAUER method ${ }^{24)}$ modified only by the use of an agar thickness of $0.2 \mathrm{~cm}$. For the determination of MICs, broth dilution studies were conducted by the microtiter technique. Volumes of $1.5 \mu \mathrm{l}$ of culture containing $10^{5}$ colony-forming units (CFU) were transferred by use of a Dynatech MIC-2000 inoculator to microtiter wells containing $0.1 \mathrm{ml}$ of a twofold serial dilution of the antibiotics in Mueller-Hinton broth. The lowest concentration showing an absence of visible turbidity or sediment after 20 hours of incubation at $35^{\circ} \mathrm{C}$ was designated the MIC. Organisms listed in Tables 3 and 4 include both isolates of typical antibiotic sensitivity and isolates selected for their resistance to $\beta$-lactam antibiotics currently in use.

UV Assay

Total carbapenem concentration in solution was determined by a difference spectrophotometric assay based on the reaction of the carbapenem chromophore $\left(\lambda_{\max } 297 \sim 300 \mathrm{~nm}\right)$ with hydroxylamine at pH 7 to form products exhibiting marginal absorbance at $\lambda_{\max }{ }^{22)}$. Since compounds $1 \sim 6$ all possess the same carbapenem chromophore and have similar $\lambda_{\max }$ values, it was assumed that all compounds have the same molar extinction coefficient $(\varepsilon)$ at $\lambda_{\max }$. Crystalline MK787 monohydrate, $\lambda_{\max } 298 \mathrm{~nm}$ ( $\varepsilon 9,670,99 \% \mathrm{NH}_{2} \mathrm{OH}$ extinction), was selected as standard. Based on this standard, pure carbapenems have the following $\mathrm{E}_{1 \mathrm{~cm}}^{1 \%}, \lambda_{\max }$ values: 1 (355), 2 (374), 3 (355), $\mathbf{4}(323), \mathbf{5}(338), \mathbf{6}(323)$. The thienamycin sample assayed $85 \%$ pure.

\section{HPLC Assay}

HPLC assays were carried out using a Waters Assoc. Model 6000A pump and a Waters Assoc. Model U6K injector. Column effluent was monitored at $297 \sim 300 \mathrm{~nm}$ with an LDC SpectroMonitor II Model 1202 UV detector equipped with a flow cell of $10 \mathrm{~mm}$ pathlength and a Honeywell Model Electronik 195 recorder. A Spectra Physics Autolab System I Computing Integrator quantitated detector output. All carbapenem pairs were satisfactorily resolved at $30^{\circ} \mathrm{C}$ using a Waters $10 \mu \mathrm{m} \mathrm{C}_{18} \mu$-Bondapak column $(4 \mathrm{~mm} \mathrm{ID} \times 300 \mathrm{~mm})$ in $0.01 \mathrm{M}$ potassium phosphate $\mathrm{pH} 7.0$. At a flow rate of $1.2 \mathrm{ml} /$ minute, the retention times (seconds) of the antibiotics are as follows: $\mathbf{2}(283), \mathbf{5}(350), \mathbf{1}(435), \mathbf{3}(465)$, 4(562), 6(615). Column performance deteriorated significantly with age. The retention times of all components decreased markedly although the relative order of elution did not change. Analysis of 1/3 mixtures was also performed using an Aminex A-5 column $(4.6 \mathrm{~mm} \mathrm{ID} \times 240 \mathrm{~mm})$. The column was operated at ambient temperature in $0.01 \mathrm{M}$ sodium phosphate $\mathrm{pH} 7.0$ containing $25 \mu \mathrm{M}$ EDTA. The flow rate was $0.2 \mathrm{ml} / \mathrm{minute.} \mathrm{Retention} \mathrm{times} \mathrm{of} \mathbf{1}$ and $\mathbf{3}$ were 2,180 seconds and 2,510 seconds respectively.

Analytical Instrumentation

NMR spectra were recorded on a Varian SC-300 spectrometer at $6^{\circ} \mathrm{C}$ in $0.02 \mathrm{M}$ sodium phosphate pD 7.8. Low resolution MS data were collected at $70 \mathrm{eV}$ on an LKB Model 9000 spectrometer. High resolution MS data were measured at $100 \mathrm{eV}$ using a Varian MAT 731 spectrometer. IR, UV, and CD spectra were determined on the following respective instruments: Nicolet Model 7199 FTIR spectrometer, Beckman Model 5260 spectrophotometer, and Jasco Model J-41A spectropolarimeter.

\section{Results}

Northienamycin and 8-epi-thienamycin were isolated from $S$. cattleya fermented to produce thienamycin. Fermentation was carried out in complex medium as described previously. ${ }^{22)}$ The isolation process is summarized in Fig. 1. The first three steps are common with thienamycin isolation and have been reported in detail elsewhere. ${ }^{25)}$ Broth was first adsorbed on Dowex 1X2 (bicarbonate), 50 100 mesh. Crude thienamycin complex was eluted from the resin with carbonic acid and chromatographed in water on Dowex $1 \mathrm{X} 2\left(\mathrm{Cl}^{-}\right), 50 \sim 100$ mesh. To this point compounds 2 and 3 co-chromato- 
Fig. 1. Isolation of northienamycin and 8-epi-thienamycin.

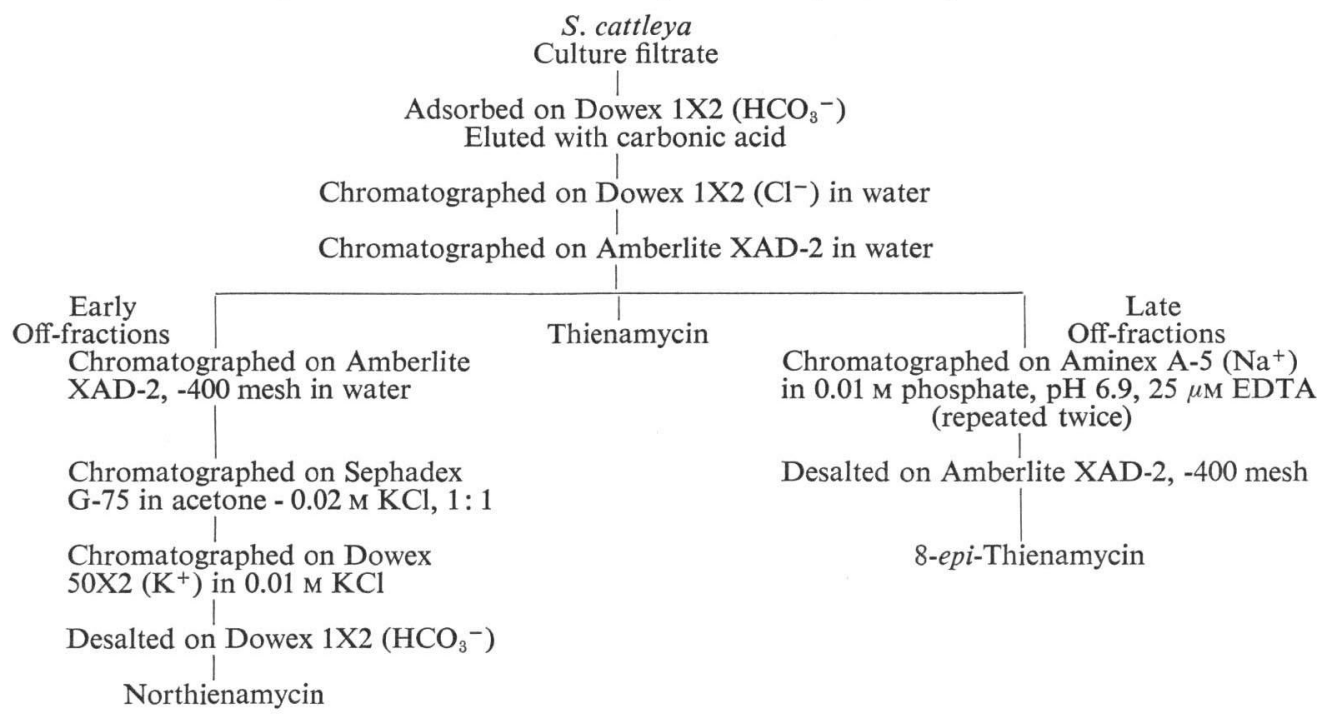

graphed with thienamycin. HPLC analyses later showed that the relative amounts of $\mathbf{1}, \mathbf{2}$ and $\mathbf{3}$ are 90: 5: 5. Subsequent chromatography on Amberlite XAD-2, $20 \sim 50$ mesh afforded essentially pure thienamycin. In addition, an early thienamycin off-fraction was found by agar disc diffusion assay to have more antibacterial activity than could be accounted for by the HPLC assay of thienamycin content. The new antibiotic component has been isolated and shown to be northienamycin. In a similar way, a late thienamycin off-fraction from the Amberlite XAD-2 step was analyzed by HPLC using an Aminex A-5 column. An effluent fraction was collected that exhibited less antibacterial activity than expected from the UV assay of the fraction for thienamycin. This result led ultimately to the isolation of 8-epithienamycin whose antibacterial potency is considerably less than that of thienamycin. Because of the pronounced instability of $\mathbf{2}$ and $\mathbf{3}$ in solution, successive isolation steps were executed with minimum delay.

The formamidine derivatives of northienamycin and 8-epi-thienamycin were most conveniently prepared by $\mathrm{N}$-formimidoylation of thienamycin and isolation of 5 and $\mathbf{6}$ as minor constituents of the reaction product.

\section{Isolation of Northienamycin}

A sample of early thienamycin off-fractions from the Amberlite XAD-2 chromatography (Fig. 1) contained $48 \mathrm{mg}$ of northienamycin and $520 \mathrm{mg}$ of thienamycin. The sample, adjusted to $\mathrm{pH} \mathrm{7,} \mathrm{was}$ chromatographed in two equal portions on $230 \mathrm{ml}$ of Amberlite XAD-2, -400 mesh in water to remove thienamycin. The northienamycin rich cut was lyophilized to $340 \mathrm{mg}$ of $10 \%$ pure antibiotic. The solid was reconstituted in $30 \mathrm{ml}$ of acetone $-0.02 \mathrm{M}$ aqueous $\mathrm{KCl}(\mathrm{pH} 7) 1: 1$, and chromatographed at $5^{\circ} \mathrm{C}$ in the same solvent on $400 \mathrm{ml}$ of Sephadex G-75. Northienamycin concentration in column effluent peaked at 2.6 column volumes. About half of the eluted northienamycin was excluded from the rich cut because of impurities indicated by HPLC assay at $300 \mathrm{~nm}$ and $220 \mathrm{~nm}$. The rich cut, containing 11 $\mathrm{mg}$ of 2, was further purified by chromatography at $5^{\circ} \mathrm{C}$ on $200 \mathrm{ml}$ of Dowex $50 \mathrm{WX} 2\left(\mathrm{~K}^{+}\right), 200 \sim 400$ mesh in $0.01 \mathrm{M} \mathrm{KCl}$. Appropriate fractions were pooled and adsorbed directly onto $40 \mathrm{ml}$ of Dowex $1 \mathrm{X} 2$ (bicarbonate), $200 \sim 400$ mesh at $5^{\circ} \mathrm{C}$. After washing the column with water, the antibiotic was 
eluted with cold carbonic acid. Lyophilization of active fractions afforded $3.8 \mathrm{mg}$ of $\mathbf{2}$ as a white solid, judged to be $60 \%$ pure by UV assay.

Isolation of 8-epi-Thienamycin

A $180 \mathrm{mg}$ sample of lyophilized late thienamycin off-fractions from the Amberlite XAD-2 chromatography (Fig. 1) contained $2.3 \mathrm{mg}$ of 8 -epi-thienamycin and $48 \mathrm{mg}$ of thienamycin. The sample was chromatographed in twelve $15-\mathrm{mg}$ portions on $8 \mathrm{ml}$ of Aminex A-5 $\left(\mathrm{Na}^{+}\right)$. The eluting solvent was $0.01 \mathrm{~m}$ sodium phosphate $\mathrm{pH} 6.9$ containing $25 \mu \mathrm{M}$ EDTA and the flow rate was $0.4 \mathrm{ml} / \mathrm{minute}$. The elution peak of 1 occurs at 1.8 column volumes and that of 3 at 2.1 column volumes. The combined rich cut from the twelve runs was rechromatographed in four portions on the same column and under the same conditions. A final third Aminex A-5 chromatography gave $0.82 \mathrm{mg}$ of 3 containing less than $1 \%$ thienamycin. The product was concentrated to $1 \mathrm{ml}$ and desalted by chromatography in water on $20 \mathrm{ml}$ of Amberlite XAD-2, -400 mesh. Lyophilization gave $1.43 \mathrm{mg}$ of 3 as a white solid, judged to be $44 \%$ pure by UV assay.

Isolation of $\mathrm{N}$-Formimidoylnorthienamycin (5) and $\mathrm{N}$-Formimidoyl-8-epi-thienamycin (6)

Thienamycin isolated by the process in Fig. 1 typically contains $2 \sim 5 \%$ each of northienamycin (2) and 8-epi-thienamycin (3). Conversion of $32 \mathrm{~g}$ of thienamycin to MK787 followed by Dowex 50WX2 chromatography ${ }^{23)}$ provided an MK787 tail fraction enriched in the corresponding formamidine derivatives of $\mathbf{2}$ and 3. The fraction assayed $57 \mathrm{mg}$ of $\mathbf{5}, 66 \mathrm{mg}$ of $\mathbf{6}$, and $500 \mathrm{mg}$ of MK787. When chromatographed in water on $250 \mathrm{ml}$ of Amberlite XAD-2, -400 mesh, the northienamycin derivative eluted at 1.4 column volumes (Rich Cut 1) while MK787 and 6 co-eluted at 2 column volumes (Rich Cut 2).

$\mathrm{N}$-Formimidoylnorthienamycin (5)

An aliquot of Rich Cut 1 containing $27 \mathrm{mg}$ of $\mathbf{5}$ was further purified by chromatography on $80 \mathrm{ml}$ of Dowex 50WX2 $\left(\mathrm{Na}^{+}\right), 200 \sim 400$ mesh. The eluant was $0.005 \mathrm{~m}$ sodium phosphate pH 7.6. After subsequent desalting on $8 \mathrm{ml}$ of the same resin in water, the antibiotic was chromatographed in water on $20 \mathrm{ml}$ of Amberlite XAD-2, -400 mesh. Freeze-drying afforded $17 \mathrm{mg}$ of $\mathbf{5}$ as a white solid, estimated to be $64 \%$ pure by UV assay.

$\mathrm{N}$-Formimidoyl-8-epi-thienamycin (6)

Rich Cut 2 was chromatographed three successive times on $300 \mathrm{ml}$ of Dowex 50WX2( $\left.\mathrm{K}^{+}\right), 200 \sim 400$ mesh. Each time the sample was charged in $0.1 \mathrm{M}$ potassium phosphate $\mathrm{pH} 8.2$ and eluted with $0.005 \mathrm{M}$ $\mathrm{KCl}$ containing $25 \mu \mathrm{M}$ EDTA, $\mathrm{pH}$ 7.2. Desalting of the final rich cut on Amberlite XAD-2, -400 mesh and subsequent lyophilization gave $11 \mathrm{mg}$ of 6 as a white solid, $66 \%$ pure. The final sample was contaminated with $7 \%$ MK787. For antibacterial testing, the MK787 content was reduced to less than $1 \%$ by purification on Aminex A-5 in 0.01 m sodium phosphate $\mathrm{pH} 7.4$.

\section{Structure of Northienamycin and 8-epi-Thienamycin}

It was suspected early in the isolation that $\mathbf{2}$ and $\mathbf{3}$ were closely related to thienamycin. The UV spectra of all three compounds exhibit single absorbance maxima at $297 \mathrm{~nm}$, which are destroyed upon treatment with hydroxylamine at $\mathrm{pH}$ 7. Both $\mathbf{2}$ and $\mathbf{3}$ are unstable in solution and are not retained at $\mathrm{pH}$ 7 on Dowex $1 \times 2\left(\mathrm{Cl}^{-}\right)$resin, properties shared by thienamycin. ${ }^{22)}$ The antibacterial profiles are also similar to thienamycin, particularly with respect to anti-Pseudomonas activity (vida infra).

Purified 2 shows strong IR absorption at $1762 \mathrm{~cm}^{-1}$ and $1610 \mathrm{~cm}^{-1}$, consistent with a $\beta$-lactam carbonyl and a carboxylate anion (Table 1). The molecular formula of 2 was established as $\mathrm{C}_{10} \mathrm{H}_{14} \mathrm{~N}_{2}$ - 
Table 1. Physicochemical properties of thienamycin (1), northienamycin (2), and 8-epi-thienamycin (3).

\begin{tabular}{|c|c|c|c|}
\hline & $\mathbf{1}$ & 2 & 3 \\
\hline Molecular formula & $\begin{array}{l}\mathrm{C}_{11} \mathrm{H}_{16} \mathrm{~N}_{2} \mathrm{O}_{4} \mathrm{~S} \\
\mathrm{MW} 272\end{array}$ & $\begin{array}{l}\mathrm{C}_{10} \mathrm{H}_{14} \mathrm{~N}_{2} \mathrm{O}_{4} \mathrm{~S} \\
\mathrm{MW} 258\end{array}$ & $\begin{array}{l}\mathrm{C}_{11} \mathrm{H}_{10} \mathrm{~N}_{2} \mathrm{O}_{4} \mathrm{~S} \\
\mathrm{MW} 272\end{array}$ \\
\hline UV (0.1 M phosphate $\mathrm{pH} 7) \lambda_{\max } \mathrm{nm}$ & 297 & 297 & 297 \\
\hline 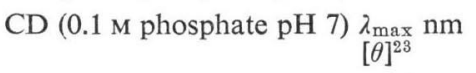 & $\begin{array}{r}288.5 \\
+23,900\end{array}$ & $\begin{array}{r}290 \\
+22,400\end{array}$ & $\begin{array}{r}289 \\
+23,200\end{array}$ \\
\hline $\operatorname{IR}(\mathrm{KBr}) \mathrm{cm}^{-1}$ & $1764,1580,1389$ & $1762,1610,1400$ & $1758,1590,1396$ \\
\hline
\end{tabular}

Fig. 2. $300 \mathrm{MHz}{ }^{1} \mathrm{H}$ NMR spectrum of northienamycin.

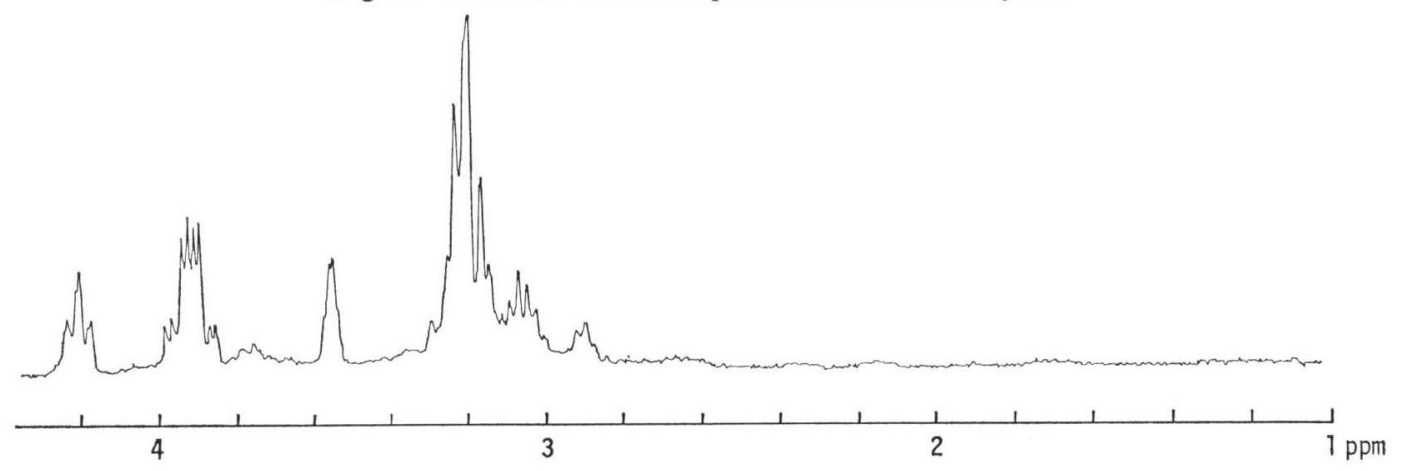

Fig. 3. $300 \mathrm{MHz}{ }^{1} \mathrm{H}$ NMR spectrum of 8-epi-thienamycin.

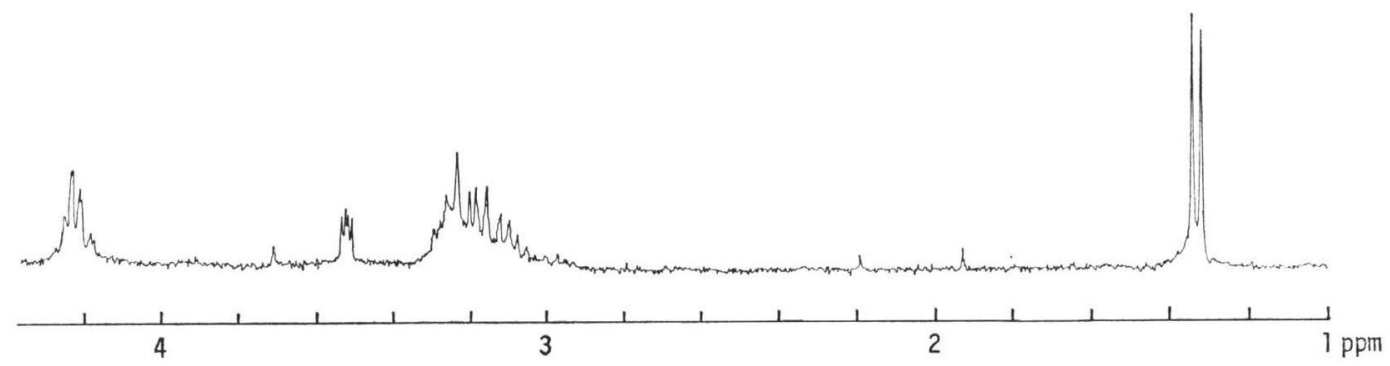

$\mathrm{O}_{4} \mathrm{~S}$ (MW 258) from high resolution MS studies of the tris-(trimethylsilyl) derivative $\left(\mathrm{M}^{+} 474.1845\right.$, calcd 474.1860 for $\mathrm{C}_{19} \mathrm{H}_{38} \mathrm{~N}_{2} \mathrm{O}_{4} \mathrm{SSi}_{3}$ ). Thus, 2 has one carbon and two hydrogens less than thienamycin. The ${ }^{1} \mathrm{H}$ NMR spectrum of $\mathbf{2}$ (Fig. 2, Table 2) shows resonances corresponding to those of $\mathrm{CH}(5), \mathrm{CH}(6)$, $\mathrm{CH}_{2}(4)$, and $-\mathrm{SCH}_{2} \mathrm{CH}_{2} \mathrm{~N}-$ of thienamycin. However, the spectrum of 2 lacks the $\mathrm{CH}_{3}(9)$ doublet of thienamycin at $\delta 1.27$ and has an additional $\mathrm{CH}_{2}-\mathrm{X}$ signal, appearing as an ABX pattern $(J=12.0,5.0$, $4.5 \mathrm{~Hz}$ ), centered at $\delta 3.92$ Double irradiation at the center of the $\delta 3.56$ methine multiplet causes collapse of the $\delta 3.92$ methylene signal to an AB quartet $(J=12.0 \mathrm{~Hz})$ and of the $\delta 4.22 \mathrm{methine}(\mathrm{dt}, J=$ $\sim 2.5,8.5 \mathrm{~Hz})$ to a triplet $(J=8.5 \mathrm{~Hz})$. This requires the sequence $\mathrm{CH}_{2}(\mathrm{X})-\mathrm{CH}-\mathrm{CH}(\mathrm{Y})$ of carbon atoms bearing protons in $\mathbf{2}$ where $\mathrm{X}$ and $\mathrm{Y}$ are of comparable deshielding effect. The data clearly establish $\mathbf{2}$ as a 9-nor analogue of thienamycin. Furthermore, the small coupling constant $(J=2.5 \mathrm{~Hz})$ between $\mathrm{CH}(5)$ and $\mathrm{CH}(6)$ requires a trans $\beta$-lactam stereochemistry. ${ }^{26,27)}$

Antibiotic 3 has strong IR absorption bands at $1758 \mathrm{~cm}^{-1}\left(\beta\right.$-lactam carbonyl) and $1590 \mathrm{~cm}^{-1}$ (carboxylate anion). Compound 3 forms a tris-(trimethylsilyl) derivative having molecular formula $\mathrm{C}_{20^{-}}$ 
Table 2. ${ }^{1} \mathrm{H}$ NMR data for thienamycin (1), northienamycin (2) and 8-epi-thienamycin (3).*

\begin{tabular}{cccc}
\hline Assignment & \multicolumn{1}{c}{$\mathbf{2}$} & \multicolumn{1}{c}{$\mathbf{2}$} \\
\hline $\mathrm{CH}_{3}(9)$ & $1.27(\mathrm{~d}, J=6.8 \mathrm{~Hz})$ & - & $1.33(\mathrm{~d}, J=6.8 \mathrm{~Hz})$ \\
$\mathrm{CH}_{2}(4)$ & $\sim 3.20(\mathrm{~m})$ & $\sim 3.2(\mathrm{~m})$ & $\sim 3.2(\mathrm{~m})$ \\
$\mathrm{CH}_{2}-\mathrm{S}$ & $\sim 3.10(\mathrm{~m})$ & $\sim 3.2(\mathrm{~m})$ & $\sim 3.2(\mathrm{~m})$ \\
$\mathrm{CH}_{2}-\mathrm{N}$ & $\sim 3.25(\mathrm{~m})$ & $\sim 3.2(\mathrm{~m})$ & $\sim 3.2(\mathrm{~m})$ \\
$\mathrm{CH}(6)$ & $3.44(\mathrm{dd}, J=2.6,6.0 \mathrm{~Hz})$ & $3.56(\mathrm{~m})$ & $3.52(\mathrm{dd}, J=2.9,4.3 \mathrm{~Hz})$ \\
$\mathrm{CH}(5)$ & $4.22(\mathrm{dt}, J=2.7,9.2 \mathrm{~Hz})$ & $4.22(\mathrm{dt}, J=\sim 2.5,8.5 \mathrm{~Hz})$ & $4.20(\mathrm{~m})$ \\
$\mathrm{CH}_{\mathrm{A}}(8)$ & $4.23(\mathrm{qn}, J=6.5 \mathrm{~Hz})$ & $3.89(\mathrm{dd}, J=4.5,12.0 \mathrm{~Hz})$ & $4.22(\mathrm{~m})$ \\
$\mathrm{CH}_{\mathrm{B}}(8)$ & - & $3.94(\mathrm{dd}, J=5.0,12.0 \mathrm{~Hz})$ & - \\
\hline
\end{tabular}

* Spectra were recorded at $300 \mathrm{MHz}$ in $0.02 \mathrm{M}$ phosphate pD 7.8 at $6^{\circ} \mathrm{C}$. Chemical shifts are reported in ppm relative to internal DDS.

Multiplicity: d, doublet; t, triplet; qn, quintet; m, multiplet.

$\mathrm{H}_{40} \mathrm{~N}_{2} \mathrm{O}_{4} \mathrm{SSi}_{3}$ (HRMS M+ 488.2019, calcd 488.2017). Therefore, the molecular formula of 3 is $\mathrm{C}_{11} \mathrm{H}_{10^{-}}$ $\mathrm{N}_{2} \mathrm{O}_{4} \mathrm{~S}$ (MW 272), identical to that of thienamycin. From the close similarity of the ${ }^{1} \mathrm{H}$ NMR spectra of 3 and thienamycin, 3 must be a diastereomer of thienamycin (Fig. 3, Table 2). The $\mathrm{CH}(6)$ methine appears as a doublet of doublets $(J=2.9,4.3 \mathrm{~Hz})$ at $\delta 3.52$. Double irradiation of $\mathrm{CH}_{3}(9)$ at $\delta 1.33$ collapsed the $\delta 4.22 \mathrm{CH}(8)$ methine multiplet to a doublet $(J=4.3 \mathrm{~Hz})$. Therefore, $\mathrm{CH}(6)$ must be coupled to $\mathrm{CH}(5)$ with the $2.9 \mathrm{~Hz}$ coupling constant, thereby requiring $\beta$-lactam stereochemistry to be trans. ${ }^{28,27)}$

Circular dichroism data on thienamycin, $\mathbf{2}$ and $\mathbf{3}$ are presented in Table 1. Molarity of solutions was determined by UV assay. The fact that all compounds exhibit positive molar ellipticities of similar magnitude suggests that $\mathbf{2}$ and $\mathbf{3}$ have the same absolute stereochemistry at C-5 as thienamycin, namely $R .^{28)} \quad$ Because $\beta$-lactam stereochemistry is trans and $\mathbf{3}$ is a diastereomer of thienamycin, the structures of 2 and 3 are 5(R),6(S)-9-northienamycin and 5(R),6(S)-8-epi-thienamycin respectively.

Table 3. Antibacterial spectrum of northienamycin and 8-epi-thienamycin.

\begin{tabular}{|c|c|c|c|c|c|}
\hline \multirow[b]{2}{*}{ Organism } & \multicolumn{5}{|c|}{ Zone of inhibition diameter $(\mathrm{mm}), 6 \mathrm{~mm}$ disc } \\
\hline & $\underset{2 \mu \mathrm{g} / \mathrm{disc}}{\mathbf{1}}$ & $\begin{array}{c}2^{*} \\
6 \mu \mathrm{g} / \mathrm{disc}\end{array}$ & $\begin{array}{c}3^{*} \\
26 \mu \mathrm{g} / \text { disc }\end{array}$ & $\begin{array}{c}\text { Carbenicillin } \\
50 \mu \mathrm{g} / \text { disc }\end{array}$ & $\begin{array}{l}\text { Cephalothin } \\
30 \mu \mathrm{g} / \text { disc }\end{array}$ \\
\hline Staphylococcus aureus 2985 & 34 & 32 & 36 & 36 & 33 \\
\hline S. aureus $2314^{* *}$ & 31 & 27 & 32 & 18 & 30 \\
\hline Enterococcus sp. 2862 & 20 & $10^{* * *}$ & 21 & 24 & 18 \\
\hline Escherichia coli 2482 & 22 & 23 & 22 & 24 & 22 \\
\hline E. coli $2964 * *$ & 22 & 22 & 23 & 0 & 15 \\
\hline Enterobacter cloacae 2647 & 22 & 22 & 22 & 21 & 20 \\
\hline E. cloacae $2646^{* *}$ & 20 & 20 & 22 & 13 & 0 \\
\hline Klebsiella pneumoniae 2921 & 22 & 22 & 20 & 13 & 22 \\
\hline K. pneumoniae $2922 * *$ & 21 & 21 & 19 & 0 & 18 \\
\hline Serratia sp. 2855 & 21 & 18 & - & 0 & 0 \\
\hline Proteus mirabilis 2830 & 15 & $16^{* * *}$ & 17 & 0 & 14 \\
\hline P. morganii $2833^{* *}$ & 14 & $14 * * *$ & 17 & 0 & 0 \\
\hline Providencia sp. 2851 & 16 & $16^{* * *}$ & - & 22 & 14 \\
\hline Pseudomonas aeruginosa 2835 & 17 & 16 & 22 & 0 & 0 \\
\hline P. aeruginosa 2824 & 29 & 20 & 30 & 19 & 0 \\
\hline
\end{tabular}

* Antibiotic contains $<1 \%$ other carbapenems.

** Strain resistant to $\beta$-lactam antibiotics.

*** Resistant colonies within zone of inhibition. 
${ }^{1} \mathrm{H}$ NMR data of the formamidine derivatives of $\mathbf{2}$ and $\mathbf{3}$ are as follows: $N$-formimidoylnorthienamycin (5) $\delta 3.18(1 \mathrm{H}, \mathrm{dd}, J=17, \sim 9$ $\mathrm{Hz}), 3.26(1 \mathrm{H}, \mathrm{dd}, J=17, \sim 9 \mathrm{~Hz}), 3.0 \sim 3.3(2 \mathrm{H}$, m), $3.60(3 \mathrm{H}, \mathrm{m}), 3.90$ ( $1 \mathrm{H}, \mathrm{dd}, J=12.0,4.5 \mathrm{~Hz}$ ), $3.95(1 \mathrm{H}, \mathrm{dd}, J=12.0,5.5 \mathrm{~Hz}), 4.20(1 \mathrm{H}, \mathrm{dt}, J=$ $\leq 3,8.0 \mathrm{~Hz}), 7.86 / 7.88\left(1 \mathrm{H}, \mathrm{s}, \mathrm{RNHCH}=\mathrm{NH}_{2}{ }^{+}\right.$ conformers); $N$-formimidoyl-8-epi-thienamycin (6) $\delta 1.32(3 \mathrm{H}, \mathrm{d}, J=6.5 \mathrm{~Hz}), \sim 3.2(4 \mathrm{H}, \mathrm{m})$, $3.51(1 \mathrm{H}, \mathrm{dd}, J=5,2.5 \mathrm{~Hz}), 3.62(2 \mathrm{H}, \mathrm{m}), 4.20$ $(2 \mathrm{H}, \mathrm{m}), 7.84 / 7.86\left(1 \mathrm{H}, \mathrm{s}, \mathrm{RNHCH}=\mathrm{NH}_{2}{ }^{+}\right.$ conformers).

\section{Antibacterial Properties}

Antibacterial activity of northienamycin (2) and 8-epi-thienamycin (3) is presented in Table 3.
Table 4. Antibacterial potency of $N$-formimidoylnorthienamycin (5) and $N$-formimidoyl-8-epi-thienamycin (6).

\begin{tabular}{|c|c|c|c|}
\hline \multirow{2}{*}{ Organism } & \multicolumn{3}{|c|}{$\operatorname{MIC}(\mu \mathrm{g} / \mathrm{ml})$} \\
\hline & MK787 & 5 & 6 \\
\hline $\begin{array}{l}\text { S. aureus } 2822 \\
\text { (ATCC } \$ 25933 \text { ) }\end{array}$ & $\leq 0.016$ & $\leq 0.016$ & $\leq 0.098$ \\
\hline S. aureus $2314^{*}$ & $\leq 0.016$ & 0.12 & 0.39 \\
\hline $\begin{array}{l}\text { E. coli } 2821 \\
\text { (ATCC } \# 25922)\end{array}$ & 0.12 & 0.50 & 6.2 \\
\hline E. coli 2895 & 0.25 & 4.0 & 6.2 \\
\hline E. cloacae 2647 & 0.12 & 0.5 & 6.2 \\
\hline E. cloacae $2646^{*}$ & 0.25 & 16 & 6.2 \\
\hline K. pneumoniae 2921 & 0.12 & 0.5 & 3.1 \\
\hline Klebsiella sp. 2888 & 0.50 & 4.0 & 6.2 \\
\hline $\begin{array}{l}P . \text { aeruginosa } 4369 \\
\text { (ATCC } \# 27853 \text { ) }\end{array}$ & 2.0 & 8.0 & 6.2 \\
\hline
\end{tabular}

Data for thienamycin, cephalothin and carbenicillin are included for comparison. Both $\mathbf{2}$ and $\mathbf{3}$ exhibit good broad spectrum activity that includes Pseudomonas aeruginosa. Discounting differences in antibiotic potency, the three carbapenems have similar spectral profiles. Relative potencies of the antibiotics, determined from the geometric means of potencies of data in Table $3,{ }^{28)}$ are the following: thienamycin 100 , northienamycin 22, 8-epi-thienamycin 11 . Resistant colonies were seen within the zone of inhibition of northienamycin against several organisms.

MIC results for formamidine derivatives $4 \sim 6$ are presented in Table 4. N-Formimidoylnorthienamycin is more susceptible to P-99 $\beta$-lactamase of Enterobacter cloacae 2646 than either MK787 or Nformimidoyl-8-epi-thienamycin.

\section{Discussion}

Two new carbapenem antibiotics, northienamycin and 8-epi-thienamycin, have been isolated from S. cattleya fermentation. Broth titers are approximately $5 \%$ of that of co-produced thienamycin. Both compounds have trans $\beta$-lactam stereochemistry $(5 R, 6 S)$ and the simple unsubstituted cysteamine side chain of thienamycin and NS-5. ${ }^{12)}$ Northienamycin is the first example of a carbapenem antibiotic with a one carbon side chain at C-6.

Although northienamycin and 8-epi-thienamycin are less potent antibacterial agents than thienamycin, both exhibit good activity against a range of organisms. Their greater effectiveness against $P$. aeruginosa strains compared to most other carbapenems can be attributed to the amino group in the cysteaminyl side chain. For instance epithienamycin C (MM 22381), the $\mathrm{N}$-acetyl analogue of 8-epithienamycin, is reported ineffective against Pseudomonas. ${ }^{28)}$ Furthermore, epithienamycin $\mathrm{C}$ appears to have approximately one-third the overall antibacterial potency of 8-epi-thienamycin. Analogous results have been reported for thienamycin/ $N$-acetylthienamycin and for epithienamycin $\mathrm{A} /$ deacetylepithienamycin A. ${ }^{28)}$

The formamidine derivatives of northienamycin and 8-epi-thienamycin are less active in vitro than MK787.

\section{Acknowledgments}

We would like to thank Jean S. KaHAn and Helmut Kropp for antibacterial data and James Stevenson for FTIR data. 


\section{References}

1) Kahan, J. S.; F. M. Kahan, R. Goegelman, S. A. Currie, M. Jackson, E. O. Stapley, T. W. Miller, A. K. Miller, D. Hendlin, S. Mochales, S. Hernandez \& H. B. Woodruff: Thienamycin. A new $\beta$ lactam antibiotic. I. Discovery and isolation. Presented at the 16th Intersci. Conf. Antimicrob. Agents Chemother., Abstract No. 227, Chicago, Oct. 1976

2) Kahan, J. S.; F. M. Kahan, R. T. Goegelman, E. O. Stapley \& S. Hernandez: N-Acetyl thienamycin. US 4,165,379, Aug. 21, 1979

3) Kahan, J. S.: Antibiotic $N$-acetyldehydrothienamycin. US 4,162,323, July 24, 1979

4) Cassidy, P. J.; E. O. Stapley, R. Goegelman, T. W. Miller, B. Arison, G. Albers-Schonberg, S. B. Zimmerman \& J. Birnbaum: Isolation and identification of epithienamycins. Presented at the 17 th Intersci. Conf. Antimicrob. Agents Chemother., Abstract No. 81, New York, Oct. 1977

5) Box, S. J.; J. D. Hood \& S. R. Spear: Four further antibiotics related to olivanic acid produced by Streptomyces olivaceus: Fermentation, isolation, characterization and biosynthetic studies. J. Antibiotics 32: $1239 \sim 1247,1979$

6) Maeda, K.; S. Takahashi, M. Sezaki, K. Innuma, H. Naganawa, S. Kondo, M. Ohno \& H. Umezawa: Isolation and structure of a $\beta$-lactamase inhibitor from Streptomyces. J. Antibiotics 30: 770 772, 1977

7) Yamamoto, K.; T. Yoshioka, Y. Kato, N. Shibamoto, K. OKamura, Y. Shimauchi \& T. Ishikura: Structure and stereochemistry of antibiotic PS-5. J. Antibiotics 33: 796 803, 1980

8) Shibamoto, N.; A. Koki, M. Nishino, K. Nakamura, K. Kiyoshima, K. Okamura, M. Okabe, R. Okamoto, Y. Fukagawa, Y. Shimauchi, T. Ishikura \& J. Lein: PS-6 and PS-7, new $\beta$-lactam antibiotics. Isolation, physicochemical properties and structures. J. Antibiotics 33: 1128 1137, 1980

9) Shibamoto, N.; M. Nishino, K. OKamura, Y. Fukagawa \& T. Ishikura: PS-8, a minor carbapenem antibiotic. J. Antibiotics 35: 763 765, 1982

10) Nakayama, M.; A. Iwasaki, S. Kimura, T. Mizoguchi, S. Tanabe, A. Murakami, I. Watanabe, M. Okuchi, H. Itoh, Y. Saino, F. Kobayashi \& T. Mori: Carpetimycins A and B, new $\beta$-lactam antibiotics. J. Antibiotics 33: 1388 1390, 1980

11) Harada, S.; S. Shinagawa, Y. Nozaki, M. Asai \& T. Kishi: C-19393 $\mathrm{S}_{2}$ and $\mathrm{H}_{2}$, new carbapenem antibiotics. II. Isolation and structures. J. Antibiotics 33: 1425 1430, 1980

12) Rosi, D.; M. L. Drozd, M. F. Kuhrt, L. Terminiello, P. E. Came \& S. J. Daum: Mutants of Streptomyces cattleya producing $N$-acetyl and deshydroxy carbapenems related to thienamycin. J. Antibiotics 34: $341 \sim$ 343,1981

13) Shoj, J.; H. Hinoo, R. Sakazaki, N. Tsuji, K. Nagashima, K. Matsumoto, Y. Takahashi, S. Kozuki, T. Hattori, E. Kondo \& K. TANAKA: Asparenomycins A, B and C, new carbapenem antibiotics. II. Isolation and chemical characterization. J. Antibiotics 35: 15 23, 1982

14) Parker, W. L.; M. L. Rathnum, J. S. Wells, Jr., W. H. Trejo, P. A. Principe \& R. B. Sykes: SQ 27,860, a simple carbapenem produced by species of Serratia and Erwinia. J. Antibiotics 35: 653 660, 1982

15) Ito, T.; N. Ezaki, K. Ohba, S. Amano, Y. Kondo, S. Miyadoh, T. Shomura, M. Sezaki, T. Niwa, M. KoJima, S. Inouye, Y. Yamada \& T. NiIdA: A novel $\beta$-lactamase inhibitor, SF-2103A produced by a Streptomyces. J. Antibiotics 35: 533 535, 1982

16) Tsuji, N.; K. Nagashima, M. Kobayashi, Y. Terui, K. Matsumoto \& E. Kondo: The structures of pluracidomycins, new carbapenem antibiotics. J. Antibiotics 35: 536 540, 1982

17) Oкаве, M.; S. Azuma, I. Kojima, K. Kouno, R. Окамотo, Y. Fukagawa \& T. Ishikura: Studies on the OA-6129 group of antibiotics, new carbapenem compounds. I. Taxonomy, isolation and physical properties. J. Antibiotics 35: 1255 1263, 1982

18) Fukagawa, Y.; T. Yoshioka, I. Kojima, M. Okabe \& T. Ishikura: New carbapenem compounds OA6129D and E produced by Streptomyces sp. OA-6129. Presented at the 22nd Intersci. Conf. Antimicrob. Agents Chemother., Abstract No. 215, Miami Beach, Oct. 1982

19) Harada, S.; Y. Nozaki, S. Shinagawa \& K. Kitano: C-19393 E 5 , a new carbapenem antibiotic. Fermentation, isolation and structure. J. Antibiotics 35: 957 962, 1982

20) Tanabe, S. ; M. Okuchi, M. Nakayama, S. Kimura, A. Iwasaki, T. Mizoguchi, A. Murakami, H. Itoh \& T. Mori: A new carbapenem antibiotic, 6643-X. J. Antibiotics 35: 1237 1239, 1982

21) Box, S. J.; D. F. Corbett, K. G. Robins, S. R. Spear \& M. S. Verrall: A new olivanic acid derivative produced by Streptomyces olivaceus: Isolation and structural studies. J. Antibiotics 35: 1394 1396, 1982

22) Kahan, J. S.; F. M. Kahan, R. Goegelman, S. A. Currie, M. Jackson, E. O. Stapley, T. W. Miller, A. K. Miller, D. Hendlin, S. Mochales, S. Hernandez, H. B. Woodruff \& J. Birnbaum: Thienamycin, 
a new $\beta$-lactam antibiotic. I. Discovery, taxonomy, isolation and physical properties. J. Antibiotics 32 ; $1 \sim 12,1979$

23) Leanza, W. J.; K. J. Wildonger, T. W. Miller \& B. G. Christensen: N-Acetimidoyl- and $N$-formimidoylthienamycin derivatives: Antipseudomonal $\beta$-lactam antibiotics. J. Med. Chem. 22: 1435 1436, 1979

24) Bauer, A. W.; W. M. M. Kirby, J. S. Sherris \& M. Turck: Antibiotic susceptibility testing by a standardized single disk method. Amer. J. Clin. Pathol. 45: 493 496, 1966

25) Treiber, L. R.; V.P. Gullo \& I. Putter: Procedure for isolation of thienamycin from fermentation broths. Biotechnol. Bioeng. 23: 1255 1265, 1981

26) Albers-Schonberg, G.; B. H. Arison, O. D. Hensens, J. Hirschfield, K. Hoogsteen, E. A. Kaczka, R. E. Rhodes, J. S. Kahan, F. M. Kahan, R. W. Ratcliffe, E. Walton, L. J. Ruswinkle, R. B. Morin \& B. G. Christensen: Structure and absolute configuration of thienamycin. J. Am. Chem. Soc. 100: 6491 6499, 1978

27) Cassidy, P. J.; G. Albers-Schonberg, R. T. Goegelman, T. Miller, B. Arison, E. O. Stapley \& J. BirnBAUM: Epithienamycins. II. Isolation and structure assignment. J. Antibiotics 34: 637 648, 1981

28) Stapley, E. O.; P. J. Cassidy, J. Tunac, R. L. Monaghan, M. Jackson, S. Hernandez, S. B. Zimmerman, J. M. Mata, S. A. Currie, D. Daoust \& D. Hendlin: Epithienamycins - novel $\beta$-lactams related to thienamycin. I. Production and antibacterial activity. J. Antibiotics 34: 628 636, 1981 